
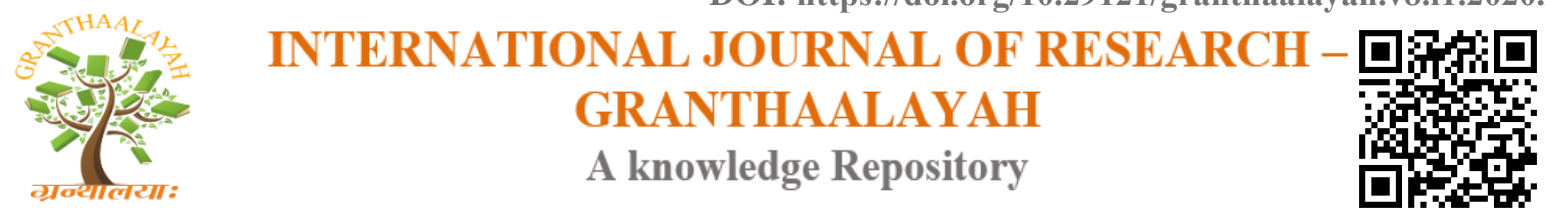

Management

\title{
AN ANALYSIS OF PSYCHOLOGICAL ORIENTATION, COMMITMENT AND EMPLOYEE PERFORMANCE IN PUBLIC INSTITUTIONS: A CASE STUDY OF KAMPALA CITY COUNCIL AUTHORITY (KCCA), UGANDA
}

\author{
Hasanati Nabayinda ${ }^{1}$, Musa Matovu ${ }^{* 2}$ \\ ${ }^{1}$ Faculty of Management Studies, Islamic University in Uganda, Uganda \\ ${ }^{* 2} \mathrm{PhD}$, Faculty Education, Islamic University in Uganda, Uganda
}

\begin{abstract}
Background: The study intended to analyze the relationship between psychological orientation, commitment and employee performance among staff in public institutions: A case study of Kampala City Council Authority (KCCA). The study tested three hypotheses; (i) there is no relationship between psychological orientation and employee commitment in KCCA; (ii) there is no relationship between commitment and employee performance in KCCA; and (iii) there is no relationship between orientation and employee performance in KCCA. A correlational research design was employed to test the relationship between the variables under study. A closed ended questionnaire was adopted to collect data for this study.

Results: From the results obtained it was observed that there is a significant positive relationship between psychological orientation and commitment, $\mathrm{r}=.668, \mathrm{p}=.015, \mathrm{~N}=213$; statistically significant positive relationship between commitment and employee performance, $\mathrm{r}=.419, \mathrm{p}=$ $.041, \mathrm{~N}=213$; and statistically significant positive relationship between psychological orientation and employee performance among the staff in KCCA, $r=.789, \mathrm{p}=.000 ; \mathrm{N}=213$.

Recommendations: The study recommends that KCCA put more efforts and resources into psychological orientation because it highly predicts employee performance than any other variable studied. It was also noted that all the variables under study were related to one another, meaning that they have statistical importance, and can be considered when improving performance of the employees at KCCA.
\end{abstract}

Keywords: Psychological Orientation; Commitment; Employee Performance.

Cite This Article: Hasanati Nabayinda, and Musa Matovu. (2020). "AN ANALYSIS OF PSYCHOLOGICAL ORIENTATION, COMMITMENT AND EMPLOYEE PERFORMANCE IN PUBLIC INSTITUTIONS: A CASE STUDY OF KAMPALA CITY COUNCIL AUTHORITY (KCCA), UGANDA.” International Journal of Research - Granthaalayah, 8(1), 176-188. https://doi.org/10.29121/granthaalayah.v8.i1.2020.266. 


\section{Introduction}

\section{Psychological Orientation}

Psychological orientation of employees is generally explicated as an acquaintance with, and alteration to, a new occupation by employees [1, 2]. This also refers to way in which newly recruited employee in an organization or education institution are inducted to new departments or work units, work environment, and to the organization itself. Conventionally, employers assume psychological orientation by introducing the new workforces the organizations' background, operational structure, policies, staff rules and regulations, and their benefits as staff among others [3]. During orientation there is as an opportunity for the employees to communicate the organization's vision, mission, core values, philosophy, and also to shape the new employees' values $[4,5,6]$. Psychological orientation is the inauguration point to the induction or training of new recruits in an organization which helps them obtain both practical and social skills, attitudes and organizational valued behaviors for them to adopt to the new work pace [7, 8]. The psychological orientation frames the new recruits in an organization into the type of personnel an organization desires to attain the organizational vision and mission $[9,4,5]$. Through the process of socialization, psychological orientations assist in transitioning new employees from being outsiders to insiders of the organization [4]. Broadly, psychological orientation is delineated as a process that is incessant and directed towards nurturing new recruits in an organization to be part of the system by permeating into them institutional core values and behaviors, philosophy, positive attitudes and quality standard $[10,11]$.

Psychological orientation of employees is a specialized training module(s) premediated for the new recruits to understand their job, be introduced to their new departments or units' co-workers, as well as to help them understand the overall corporate culture and communication channels [3]. In the various studies undertaken, there are three (3) paramount organizational psychological orientation processes that have been commonly used to induct new recruits in organizations. These include ambivalent, indifferent, and upward mobile psychological orientation [12]. The identified types of psychological orientation give a new experience to the new recruits as regards motivation and satisfaction of their job, organization productivity, and the various communication channels within the organization. Orientation is also constituted as self-directed, mentored and formal orientations $[13,14,15]$. During psychological orientations new recruits might be offered a chance to have self-directed job induction. Under self-directed orientation the new recruits in their first days (first week) of their job they are provided with several materials and resources that might include videos, tapes, CD's, online induction modules, typed hand-outs to read, watch or listen in order to understand the new organization better. Also, during orientation mentoring in from of peer mentoring might be tapped to make the new recruits be adequately integrated into the new working environment. During the mentoring process as part of induction of the new staff in an organization they are allocated with a senior staff to supervise them for a given period of time, and also he/ she is provided with the responsibility of introducing them to the new work environment. Mentoring during induction directs the new recruits technical, social, moral, perceptual and attitudinal skills in line with those of their new employment $[16,17,18,19,64]$. It can be noted that there is no definite time devoted to psychological orientation in organizations. Also, it is noted that psychological orientation programmes might involve direct or indirect training that might be in form of classroom learning, virtual orientation, self-directed orientation, guidance and mentoring, 
among others directed in a given period of time [20]. Generally, psychological orientation helps new recruits to familiarize with their new jobs and situations that might not be similar with their previous jobs.

\section{Employee Commitment}

Employee commitment is conceptualized as a psychological state of mind that holds employees obliged to stay with their job or organization(s) longer, and it is foreseen as a key to reducing employee turnover $[21,22,23,24]$. Committed employees have a positive focused understanding to the vision, mission and core values of their job. They also bind them to their job during the course of action and when performing their duties [21, 25, 26]. Employee commitment can also be explicated as a sense of attachment by employee(s) to their employers or employing institutions, and enthusiasm to work for the employer or institution for a longer period of time, and diligently [27]. Commitment means that the employees wish to continue and also preserve their affiliation to the institution employing them, and also are enthusiastic to support the institution or organization to achieve its vision through attesting to its mission and core values [28, 29]. Organizational commitment is a delicate and intangible attribute that is internal but can be demonstrated by employees through their attitudes and behaviours to which it can be concluded to whether employees are committed or not committed to their job or organizations [30,31]. Commitment can also be pointed to as a perception or belief an employee has that demonstrates the power of attachment an employee has to his employer, or employing organization [30. 32, 33, 63]. Commitment is again pointed to as a degree of the measure of worker's attachment or sympathy with a specific job, or institution. Employee commitment presupposes that employees will use their qualifications, experiences, skills and capabilities in a useful manner that directs the organization to achieve its vision and goals, shortly or in a long run $[8,28,29,34]$.

Organizational commitment is reflected in the workers' aspirations to uphold their attachment to their job or organization, and their enthusiasm to support the organizations or institutions to achieve their visions, and both their short and long term plans [29, 33]. [35, 36] highlight that; a) commitment is a convinced perception or belief and allegiance an employee has to the institutional vision, mission, core values and goals of the organization; b) the positive or supportive inclination of an individual to the organization goals; and c) unlimited affection for one to become party to a given group. In the same line, organizational commitment is explained as; (i) Normative commitment which underscored as employees stay on job because they think they have an obligation to stay with the organization. (ii) Affective commitment which is an emotional affection an employee expresses towards his organization by accepting to remain with the organization despite of having similar organizations, while; (iii) continuance commitment means that employees would stay on job or with the organization after contemplating on costs and benefits of that particular job, or organization $[36,37]$.

\section{Employee Performance}

Unit performance of individuals and groups is in general reflected to the total performance of the whole organization, or institution $[38,39,40]$. That is, each individual or group performance in an organization has a big role to play on the overall performance of the organization, or institution. In measuring employee performance in organizations this can be undertaken using a number of 
methods. According to different studies employee performance can be measured using; (1) time employees spend and utilize at work, length of service, punctuality at work, and tenure undertaken by individual employee; (2) cooperation, that means how employees interact and work with others to achieve the organizational vision and goals; (3) the quality of the results obtained by the organization, clarified using the number of tasks performed accurately, errors committed during work, and the number of times a given task(s) is/ are performed; and (4) the quality and quantity of products and services produced [41, 42, 36, 43]. [44] advocated for six primary aspects to underscore organizational performance. These included; (a) timeliness, the period spent to complete the allocated work; (b) quantity, the right measure of a product or service is manufactured; and (c) quality, which is the notch the results, services or products meet the required degree for purpose or perfection they are designed to achieve. Also, (d) administration, the level to which employees can work with minimum supervision; (e) interpersonal relation, the level to which workers uphold self-respect, corporate image, and good working relationship among fellow workmates; and (f) cost effectiveness, the extent to which technical, financial, technological, human and material resources of the organization are used optimally. All these lead to the efficiency and effectiveness of the organization that is reflected in the total organizational productivity.

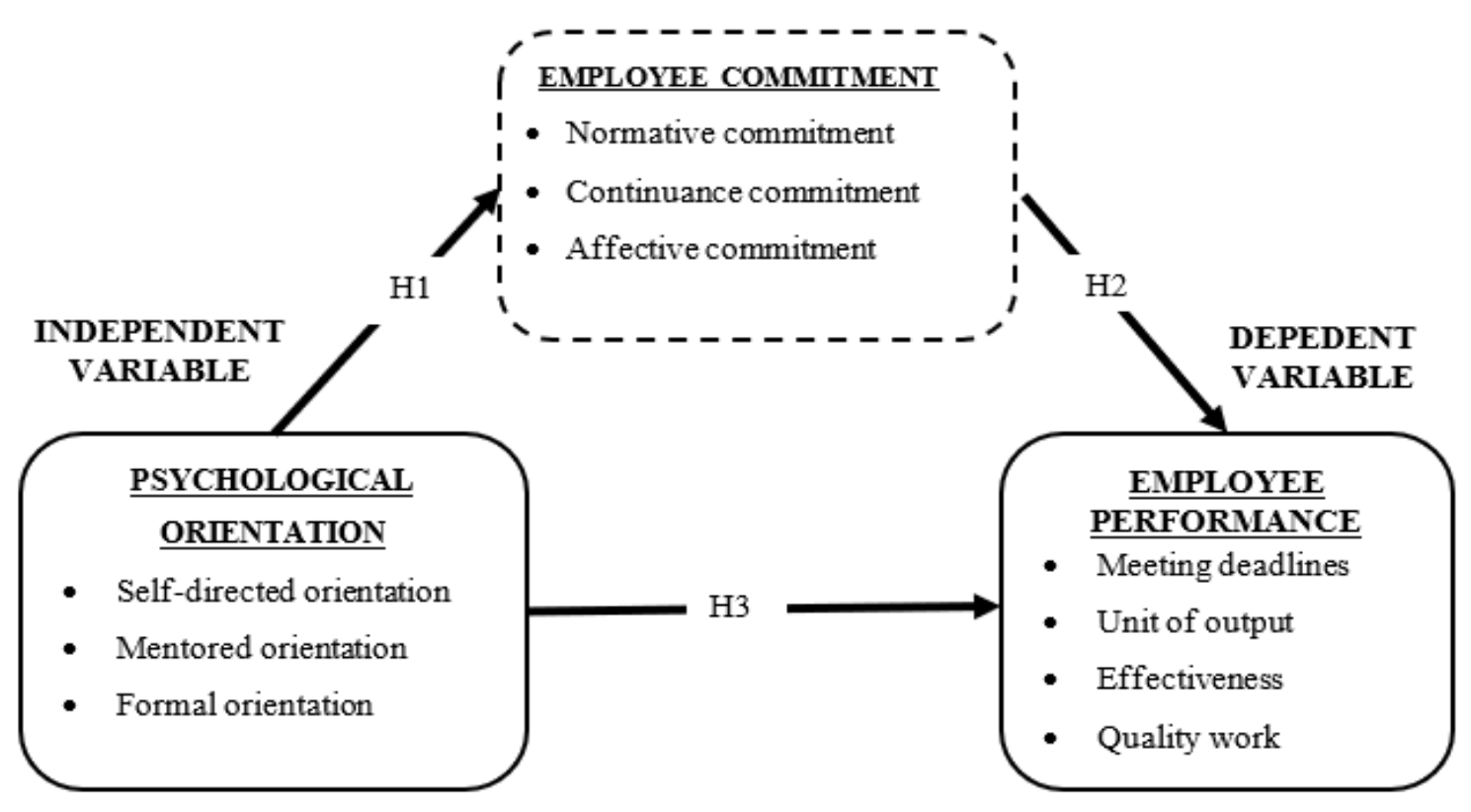

Figure 1: Psychological Orientation, Employee Commitment and Employee Performance

Figure 1 represents the structural relationships between psychological orientations and its effects on employee performance variables. Psychological orientation is the independent variable where it is constituted as self-directed, mentored and formal types of orientation. The psychological orientations were chosen as the study assumed that they would have closer relationships with employee performance in terms of meeting deadlines, maximum outputs, effectiveness, and quality of work depending on the employee commitment denoted normative, continuance and affective commitment. The framework was used to hypothesize that there is no relationship between psychological orientation and employee commitment; psychological orientation and employee performance; and employee commitment is not related to employee performance. 


\section{Theoretical Review}

According to [45] imitation, observation and modelling are the cores for cognitive and behavioral learning as stated by the social learning theorists. The supremacy of observational learning is characterized by strength founded in social learning theory guided by the causal model of person - environment interaction with intellectual contribution, self-efficiency and the intervention being part of the chain. As defined by [46] and [47] the social learning theory emphases that learning through observations might be through paring of individuals, socialization, mentoring and through guidance by those who are more informed. In the social learning theory also self-reflection, personal experiences, group consultations, personal constructivism were included in the framework. This presumes that through psychological orientation new employees get opportunity to identify what, when, where and how to meet their expectations which will fulfill the requirement of employer through accomplishing the organizational goals. Psychological orientation programs should be able to adequately settle new recruits in their new working environment. Also, organizations should focus on how to conduct good psychological orientation programs that address strategies to improve employee performance, productivity and to reduce employee turnover. According to [48] emphasize committed employees are those committed to their jobs or organizational objectives which is demonstrated through employee attitudes and behaviors that reflect continuity of their services with the organization, and also committed to achieving the organizational vision and goals. [49] revealed that good performance of employees should be reflected in the total organization's performance which is reflected in the organization's productivity.

This study sought to analyze the relationship between psychological orientation, commitment and employee performance in public institutions: A case study of KCCA - Uganda. The study analyzed the following hypotheses.

1) There is no relationship between psychological orientation and employee commitment in Kampala City Council Authority.

2) There is no relationship between commitment and employee performance in Kampala City Council Authority.

3) There is no relationship between psychological orientation and employee performance in Kampala City Council Authority.

\section{Methods}

The methods used in this study are explained as follows.

\subsection{Research Design}

The study employed a correlational research design and a quantitative approach to conduct the research. The correlational research design was adopted to analyze the relationship between the psychological orientation, commitment and employee performance in Kampala City Council Authority. 


\subsection{Population, Sample and Sampling Techniques.}

The target population of this study was 455 employees from 11 directories. The study used Yamane's formula for calculating the sample size [50]. According to him, for a $95 \%$ confidence level and $p=0.05$, the size of the sample should be where, $\mathrm{N}$ is the population size, and e is the level of precision $(p=0.5)$. In the context of this study, $\mathrm{N}=455$ with $95 \%$ level of precision. Assuming 95\% confidence level and $p=0.05$, we get the sample size as

$$
n=\frac{N}{1+N(e)^{2}} \quad n=\frac{455}{1+455\left(0.05^{2}\right)}=213
$$

The sample size for this study was 213. Samples from the different directorates were computed using stratified sampling further supplemented with simple random sampling technique, which provided every member of population same and known chances of being nominated in each strata hence stratified random sampling [50].

A sample of 213 was selected from a population of 455 staff in the different departments of Kampala City Council Authority (KCCA). A sample was selected using both simple random sampling and convenience sampling from the following departments; education, human resource, physical planning, treasury, revenue collection, engineering and technical services, public health and environment services, legal affairs, gender and community services, internal audit, and Office of the Executive Director.

\subsection{Instrument of Data Collection}

A closed ended questionnaire was used to gather the required data for this study.

\subsubsection{Questionnaire}

The 30 rated item questionnaires were developed based on three study variables; psychological orientation (10 items), commitment (10 items) and employee performance (10 items). This questionnaire was rated based on a five-point Likert scale model descending from $5=$ strongly agree, $4=$ agree, $3=$ neither agree nor disagree, $2=$ disagree, to $l=$ strongly disagree. Also, the questionnaire had to collect biodata from the respondents.

\subsubsection{Validity and Reliability}

In determining the reliability of the instruments Kappa statistics were employed. Three (3) raters were used to determine the validity of the instruments of data collection. A Cronbach's alpha coefficient of 0.9 was obtained meaning that the instrument was reliable to collect the data for the study, and content validity index of .84 was obtained as regards the validity test results. According to the Cronbach's alpha coefficient and Content Validity Index results it is indicated that the instrument of data collection was both valid and reliable to collect data for the study. 


\subsubsection{Data Analysis}

The study used both inferential and descriptive statistics to provide ground to scrutinize the data gathered during the study. Descriptive analyses were used to analyze the bio-data for the respondent while inferential statistics were used to examine the relationship between the variables under study; psychological orientation, commitment and employee performance.

\section{Results}

This section presents and analyses the findings of the study. Table 1 presents the characteristics of the respondents as regards their gender and age.

Table 1: Gender, Age and Level of the Respondents

\begin{tabular}{|l|l|c|c|}
\hline \multirow{4}{*}{ Gender } & & Frequency & Percentage (\%) \\
\hline \multirow{5}{*}{ Age } & Male & 99 & 46.5 \\
\cline { 2 - 4 } & Female & 114 & 53.5 \\
\cline { 2 - 4 } & Total & $\mathbf{2 1 3}$ & $\mathbf{1 0 0 . 0}$ \\
\cline { 2 - 4 } & less 20 yrs. & 25 & 11.7 \\
\cline { 2 - 4 } & $(20-30)$ yrs. & 45 & 21.1 \\
\cline { 2 - 4 } & $(31-40)$ yrs. & 95 & 44.6 \\
\cline { 2 - 4 } & 40+yrs & 48 & 22.5 \\
\cline { 2 - 4 } & Total & $\mathbf{2 1 3}$ & $\mathbf{1 0 0 . 0}$ \\
\hline \multirow{5}{*}{ Level } & Administrators & 24 & 11.3 \\
\cline { 2 - 4 } & Junior employees & 155 & 72.8 \\
\cline { 2 - 4 } & Supervisors & 34 & 16.0 \\
\cline { 2 - 4 } & Total & $\mathbf{2 1 3}$ & $\mathbf{1 0 0 . 0}$ \\
\hline
\end{tabular}

Source: Field data, 2019

According to the results in Table 1 it is shown that 99 (46.5\%) of the respondents were males and $114(53.5 \%)$ were females. Also, the age results highlight that most of the respondents were in age group of (31-40) years, these were 95(44.6\%), followed by those in age group was 40 years and above who were 48 (22.5\%), followed by those in age group of (20-30) years who were $45(21.1 \%)$, and lastly were those less than 20 years of age, these were $25(11.7 \%)$. Majority of the respondent being above 30 years of age and this indicates that the participants were not only from office of high responsibility but were also mature enough to give their opinions on whatever was asked to them. Most of the respondents were junior employees who were 155 (72.8\%). These were followed by supervisors who were $34(16 \%)$ and the least were administrators who were $24(11.3 \%)$ 
Table 2: Correlation Between Psychological Orientation, Commitment and Employee Performance

\begin{tabular}{|l|l|c|c|c|}
\hline & & $\begin{array}{c}\text { Psychological } \\
\text { Orientation }\end{array}$ & Commitment & $\begin{array}{c}\text { Employee } \\
\text { performance }\end{array}$ \\
\hline \multirow{5}{*}{$\begin{array}{l}\text { Psychological } \\
\text { Orientation }\end{array}$} & $\begin{array}{l}\text { Pearson } \\
\text { Correlation }\end{array}$ & 1 & $.668^{*}$ & $.789^{* *}$ \\
\cline { 2 - 5 } & Sig. (2-tailed) & & .015 & .000 \\
\cline { 2 - 5 } & $\mathrm{N}$ & 213 & 213 & 213 \\
\hline Commitment & $\begin{array}{l}\text { Pearson } \\
\text { Correlation }\end{array}$ & $.668^{*}$ & 1 & $.419^{*}$ \\
\cline { 2 - 5 } & Sig. (2-tailed) & .015 & 213 & .041 \\
\cline { 2 - 5 } performance & $\mathrm{N}$ & 213 & $.419^{*}$ & 213 \\
\hline \multirow{5}{*}{$\begin{array}{l}\text { Employee } \\
\text { Correlation }\end{array}$} & $.789^{* *}$ & .041 & 1 \\
\cline { 2 - 5 } & Sig. (2-tailed) & .000 & 213 & 213 \\
\cline { 2 - 5 } & $\mathrm{N}$ & 213 & & \\
\hline
\end{tabular}

**. Correlation is significant at the 0.01 level (2-tailed).

*. Correlation is significant at the 0.05 level (2-tailed).

According to the results in Table 2, a statistically significant positive relationship between psychological orientation and commitment was observed; $\mathrm{r}=.668, p=.015, \mathrm{~N}=213$. Also, the results highlight a statistically significant positive relationship between commitment and employee performance; $\mathrm{r}=.419, p=.041, \mathrm{~N}=213$. It was again noted that there is a statistically significant positive relationship between psychological orientation and employee performance among the staff in KCCA; $r=.789, p=.000 ; \mathrm{N}=213$. From the obtained results in Table 2, it is noted that all the variables studied had a significant relationship between the variables they were correlated with.

In an observation to understand the effect of one variable onto the other among the variables studied, a unit change in psychological orientation will bring $66.8 \%$ positive change in employee commitment to their jobs. It is noted that a unit change in commitment will lead to a $41.9 \%$ positive change in the employee performance on their jobs. It is again observed that a unit change in psychological orientation leads to $78.9 \%$ positive change in the employee performance on their jobs in KCCA.

\section{Discussion and Conclusions}

By providing psychological orientation this helps organizations in achieving higher levels of employee performance [28, 8, 29]. Psychological orientation helps employees to get to know what they are supposed to do and how to do it before they start their engagement with the new assignments [8]. With the employees knowing what they are supposed to do helps them to minimize errors they commit during work, and thus increasing their performance. According to different studies psychological orientation to new inductions is one of the abandoned purposes in many establishments [51, 52, 8]. Due to lack of appropriate psychological orientation 
organizations bear a cost of losing the competitive and well-trained employees because they are not aware of what has to be done, or fail to understand the whole organization system. Failure to understand that organizational systems might be a demotivating factor that can send away competent employees from an organization [53, 8]. From the results of this study it can be noted that well planned and managed psychological orientations can lead to proper employee performance. This is because having good psychological orientations makes new employees to develop positive attitudes and a sense of belonging towards their work [54, 28, 8].

With formal psychological orientation given to new employees this helps to manage and also retain employees for longer periods $[55,56]$. Also, this has been noted to help in decreasing the turnover rate within organizations which results into increased productivity level and improves employee morale [57]. Psychological orientation helps to build the relationship between new employees to the organizational values and practices. Psychological orientation provides the basic guidance which help the employees to learn new things related to new job [28, 56]. Employee commitment has also been seen to improve employee performance. From the evidence adduced from the results of the study, it is noted that organizational performance can be greatly improved by having committed employees $[58,28,56,59]$. The findings of this study have discovered that there exists a linkage between employee commitment and employee performance in public institutions in Uganda with a case study of a vibrant organization (KCCA). Attitudes and behaviors might be used to explain how committed employees might be to their jobs. So, it is imperative for organizations to change behaviors and attitude of their workers in lieu to commit them to their work [60]. Public organizations should explore the various determinants of employees' commitment in order to increase organization efficiency and effectiveness. The psychological orientation has an influence on the way employees perform at their places of work. The results derived out of this study explicitly highlight that they are consistent with the results from earlier studies of psychological orientation and employee performance $[61,8,55,56]$.

In a nut shell, the results obtained from this study are steadfast with the views enshrined in the adult learning theory [62] as well as social learning theory because they highlight the significant relationships between psychological orientation and commitment as well as psychological orientation and employee performance were positive and significant results were obtained. Also, the results were consistent with the affective events theory which highlighted that a significant positive relationship between commitment and employee performance existed.

\section{References}

[1] Aizzat M. N., Ahmad, N. H., \& Tan, C. L. (2016). The Role of Staffing and Orientation Practices in Predicting Service-Oriented Organizational Citizenship Behaviour. Asian Academy of Management Journal, 21(2), 27-51.

[2] Nyavor A. (2012). The Effect of Employee Orientation On Performance in The Ghana Education Service. A Case of the Greater Accra Region. Unpublished Dissertation, Kwame Nkrumah University of Science Technology, Kenya.

[3] Olushola, D. E., Onafadejiadeniyi. O., Ogundejititobiloluwa. Y. (2018). The Effect of Employees' Orientation on Risk Management in Leigh and Lloyd Mining Firm. International Journal of Business and Management Invention, 7(4), 20-27.

[4] McHan, C. B. (2015). Effective Methods of Communicating Organizational Values: A Case Study. Unpublished Master's Thesis, Andrews's University. 69. 
https://digitalcommons.andrews.edu/theses/69

[5] Tsai, Y. (2011). Relationship between Organizational Culture, Leadership Behavior and Job Satisfaction. BMC health services research, 11, 98. https://doi.org/10.1186/1472-6963-11-98

[6] Asare-Bediako, K. (2008). Professional Skills in Human Resource Management, 2nd Edition, Asare-Bediako and Associates, Kasoa, Ghana.

[7] Sobral F., Liliane, F., \& Gazi, I., (2017). The Pathways that make New Public Employees Committed: A Dual-Process Model Triggered by Newcomer Learning. Journal of Public Administration Research and Theory, 27, 4, $692-709$.

[8] Nassazi, A. (2013). Effects of Training On Employee Performance: Evidence from Uganda. Unpublished Masters' Dissertation, University of Applied Sciences, Germany.

[9] Olubunmi, O. F. (2015). Knowledge Management as an Important Tool in Organizational Management: A Review of Literature. Library Philosophy and Practice, 1238. http://digitalcommons.unl.edu/libphilprac/1238

[10] Petrill, T. T. (2013). The Effect of Personal Values, Organizational Values, and PersonOrganization Fit on Ethical Behaviors and Organizational Commitment Outcomes among Substance Abuse Counselors: A Preliminary Investigation. Unpublished Doctor of Philosophy Thesis, University of Iowa. https://doi.org/10.17077/etd.uzvjk997

[11] Darling-Hammond, L., Cook-Harvey, L. F. C., Barron, B., \& Osher, D. (2019). Implications for Educational Practice of the Science of Learning and Development, Applied Developmental Science, 1 - 45. https://doi.org/10.1080/10888691.2018.1537791

[12] Todorovic, D., Cabarkapa, M., Tosic-Radev, M., \& Miladinovic, I. (2017). Organizational Identification, Commitment and Orientations of Professional Military Personnel. Vojnosanit Pregl, 74(9), 871-877. https://doi.org/10.2298/VSP160616365T

[13] Sultana, R., \& Malik, O. F. (2019). Is Protean Career Attitude Beneficial for Both Employees and Organizations? Investigating the Mediating Effects of Knowing Career Competencies. Frontiers in Psychology, 10, 1284. https://doi.org/10.3389/fpsyg.2019.01284

[14] Kim, S. (2017). Learning Goal Orientation, Formal Mentoring, and Leadership Competence in HRD: A Conceptual Model. Journal of European Industrial Training, 31(3),181-194. https://doi.org/10.1108/03090590710739269

[15] Chadwick, I. C., \& Raver, J. L. (2012). Motivating Organizations to Learn: Goal Orientation and Its Influence on Organizational Learning. Journal of Management 41(3), 957-986. https://doi.org/10.1177/0149206312443558

[16] Inzer, L. D. (2005). A Review of Formal and Informal Mentoring: Processes, Problems, and Design. Journal of Leadership Education, 4(1), 31 - 50.

[17] Nadine, J. C. A. (2017). Mentorship Experiences of Women Leaders in Adventist Higher Education Institutions. Journal of Research Initiatives, 2(3), 1 - 11. http://digitalcommons.uncfsu.edu/jri/vol2/iss $3 / 4$

[18] Shandu, S. C. O. (2015). From the Industry to The Classroom: Exploring Mentoring Needs of Novice Lecturers in a TVET College. Unpublished master's Dissertation, University of KwaZuluNatal, South Africa.

[19] Shah, K., \& Khan, N., (2016). Need of Mentoring to Enhance the Teaching Skills of Newly Inducted Teachers at Primary Level in District Swat. Educational Research International, 5 (1), 66-73.

[20] Merriam, S. B., \& Brockett, R. G. (2007). The Profession and Practice of Adult Education: An Introduction. San Francisco: John Wiley \& Sons, inc.

[21] Prabhakar, G. V. (2011). Antecedent HRM Practices for Organizational Commitment. International Journal of Business and Social Science, 2(2), 55 - 62.

[22] Satardien, M. (2014). Perceived Organizational Support, Organizational Commitment and Turnover Intentions Amongst Employees in a Selected Company in the Aviation Industry. Unpublished Master's Thesis. University of the Western Cape, South Africa. 
[23] Larkin, I. M. (2015). Job Satisfaction, Organizational Commitment, and Turnover Intention of Online Teachers in the K-12 Setting. Unpublished PhD Dissertation, Kennesaw State University.

[24] Saridakis, G., Lai, Y., Munoz-Torres, R. I., \& Gourlay, S. (2018). Exploring the Relationship between Job Satisfaction and Organizational Commitment: An Instrumental Variable Approach. The International Journal of Human Resource Management. https://doi.org/10.1080/09585192.2017.1423100

[25] Zappala, S., Toscano, F., \& Licciardello, S. A. (2019). Towards Sustainable Organizations: Supervisor Support, Commitment to Change and the Mediating Role of Organizational Identification. Sustainability, 11, (805), 1-12. https://doi.org/10.3390/su11030805

[26] Meyer, J. P., Becker, T. E., \& Vandenberghe, C. (2005). Employee Commitment and Motivation: A Conceptual Analysis and Integrative Model. Journal of Applied Psychology 89(6),991-1007. https://doi.org/10.1037/0021-9010.89.6.991

[27] Priya, B., \& Kumari, P. (2017). Organizational Commitment: A Comparative Study of Public and Private Sector Bank Managers. International Journal of Business and Management Invention, 6(1), 38-47.

[28] Vance, J. R. (2006). Employee Engagement and Commitment: A Guide to Understanding, Measuring and Increasing Engagement in Your Organization. SHRM Foundation.

[29] Dobre, O. I. (2013). Employee Motivation and Organizational Performance. Review of Applied Socio- Economic Research, 5(1), 53 - 60.

[30] Grego-Planer, D. (2019). The Relationship between Organizational Commitment and Organizational Citizenship Behaviors in the Public and Private Sectors. Sustainability, 11(6395), 1-20. https://doi.org/10.3390/su11226395

[31] Abid, G., Contreras, F., Ahmed, S., \& Qazi, T. (2019). Contextual Factors and Organizational Commitment: Examining the Mediating Role of Thriving at Work. Sustainability, 11(4686), 1-18. https://doi.org/10.3390/su11174686

[32] Oh, H. S. (2019). Organizational Commitment Profiles and Turnover Intention: Using a PersonCentered Approach in the Korean Context. Frontiers in Psychology, 10, 1499. https://doi.org/10.3389/fpsyg.2019.01499

[33] Mete, E. S., Sokmen, A., \& Biyik, Y. (2017). The Relationship between Organizational Commitment, Organizational Identification, Person-Organization Fit and Job Satisfaction: A Research on IT Employees. International Review of Management and Business Research, 5(3), 870-880.

[34] Iqra, A., Yahya, R., \& Tahira, U. (2013). Effect of Organizational Learning and Knowledge Management Practices of Organizational Performance. Journal of Basic and Applied Scientific Research, 3(5), 34-39.

[35] Mohsan, F., Nawaz, M. M., Khan, M. S., Shaukat, Z., \& Aslam, N. (2011). Are Employee Motivation, Commitment and Job Involvement Inter-Related: Evidence from Banking Sector of Pakistan. International Journal of Business and Social Science, 2, 226-233.

[36] Mohsan, F., Nawaz, M. M., Khan, M. S., Shaukat, Z., Islam, T., \& Aslam, N. (2011). Impact of Job Involvement on Organizational Citizenship Behavior (OCB) and In-Role Job Performance: A Study on Banking Sector of Pakistan. European Journal of Social Sciences, 24(4), 494-502.

[37] Nkhukhu-Orlando, E., Brown, B., Wilson, B. R., Forcheh, N., Linn, J. G., \& Fako, T. T. (2019). The Affective Commitment of Academics in a University in Botswana. International Journal of Educational Administration and Policy Studies, 11(2), 12-19. https://doi.org/10.5897/IJEAPS2019.0595.

[38] Rafiei, N., \& Davari, F. (2015). The Role of Human Resources Management On Enhancing the Teaching Skills of Faculty Members. Materia Socio-Medical, 27(1), 35-38. https://doi.org/10.5455/msm.2014.27.35-38

[39] McMahon, G. (2013). Performance Management in Human Resource Management (Carbery, R., Cross, C. Eds.). Palgrave Macmillan, 2013. ISBN-13: 978-1137009395 
[40] Bakker, A. B. (2017). Strategic and Proactive Approaches to Work Engagement. Organizational Dynamic, 46(2), 67-75.

[41] Sukri, S., Asogan, P., \& Waemustafa, W. (2015). Factor Influencing Job Involvement in Universiti Malaysia Perlis (UniMAP). Mediterranean Journal of Social Sciences, 6(6), 157-167.

[42] Tiwari, V., \& Singh, S. K. (2014). Moderation Effect of Job Involvement on the Relationship Between Organizational Commitment and Job Satisfaction. Sage Open, 1-7. https://doi.org/10.1177/2158244014533554

[43] Rotenberry, P. F., \& Moberg, P. J. (2007). Assessing the Impact of Job Involvement On Performance. Management Research News, 30, 203-215

[44] Bernardin, H. J., \& Russell, J. E. A. (1998). Human Resource Management: An Experiential Approach. (2nd Ed.). New York: The McGraw-Hill Companies, Inc.

[45] Miller, N. E., \& Dollard, J. (1941). Social Learning and Imitation. New Haven: Yale University Press.

[46] Bandura, A. (1977). Social Learning Theory. Prentice Hall.

[47] Griffin, E. (2006). Social Learning Theory of Albert Bandura. Chapter 31: A First Look at Communication Theory (pp. 367-377). McGraw-Hill.

[48] Sharma, J. P., \& Bajpai, N. (2010). Organizational Commitment and its Impact On Job Satisfaction of Employees. A Comparative Study in Public and Private Sector in India. International Bulletin of Business Administration, 9, 7-19.

[49] Lapiņaa, I., Mauranea, G., \& Starinecab (2014). Human Resource Management Models: Aspects of Knowledge Management and Corporate Social Responsibility. Procedia - Social and Behavioral Sciences, 110, $577-586$.

[50] Yamane, T. (1967). Statistics: An Introductory Analysis, 2nd Ed., New York: Harper and Row.

[51] Dragomiroiua, R., Hurloiua, I. I., \& Mihaia, G. (2014). Induction Staff Training. Procedia Economics and Finance, 16, $368-373$.

[52] Acevedo, J., \& Yancey, G. B. (2015). Assessing New Employee Orientation Programs. Journal of Workplace Learning 23(5), 349 - 354. https://doi.org/10.1108/13665621111141939

[53] Abu- Jarour, S. F. (2014). Person Demotivation in Organizational Life. International Journal of Business and Social Science, 5 (1), 215 - 219.

[54] St-Amand, J. (2017). Sense of Belonging at School: Defining Attributes, Determinants, and Sustaining Strategies. IAFOR Journal of Education, 5(2), $105-119$.

[55] Caldwell, C., \& Peters, R. (2018). New Employee Onboarding Psychological Contracts and Ethical Perspectives. Journal of Management Development, 37(1), 27-39. https://doi.org/10.1108/JMD10-2016-0202

[56] Bauer, T. N. (2017). Onboarding New Employees: Maximizing Success: SHRM Foundation's Effective Practice Guidelines Series.

https://www.shrm.org/hr-today/trends-and-forecasting/special-reports-and-expertviews/Documents/Onboarding-New-Employees.pdf

[57] Ijigu, A. W. (2015). The Effect of Selected Human Resources Management Practices on Employees' Job Satisfaction in Ethiopian Public Banks. Emerging Markets Journal, 9(1), 1-16.

[58] Singh, S. P., \& Karli, J. (2015). The Impact of Job Engagement and Organizational Commitment on Organizational Performance. The International Journal of Business \& Management, 3(4), 4955.

[59] Abasilim, U. D., Gberevbie, D. E., \& Osibanjo, O. A. (2019). Leadership Styles and Employees' Commitment: Empirical Evidence from Nigeria. Sage Open, 1 - 15. https://doi.org/10.1177/2158244019866287

[60] Gul, Z. (2015). Impact of Employee Commitment on Organizational Development. FWU Journal of Social Sciences, 9 (2), 117-124.

[61] Worlu R., Mugri R., \& Akpakip C.E. (2017). Effect of Employee Orientation in Creating Satisfaction with Work. The Business and Management Review, 9 (2), 219 - 227. 
[62] Robinson, E. A., \& Jacobson, N. (1984). Social Learning Theory and Family Psychopathology. In: Jacob T. (eds) Family Interaction and Psychopathology. Applied Clinical Psychology. Springer, Boston, MA

[63] Tella, A., Ayeni, C. O., \& Popoola, S. O. (2007). Work Motivation, Job Satisfaction, and Organizational Commitment of Library Personnel in Academic and Research Libraries in Oyo State, Nigeria. https://digitalcommons.unl.edu/libphilprac/118.

[64] Santamaria, J. O. (2003). Mentoring Develops High-Potential Employees. Asia Africa Intelligence Wire.

*Corresponding author.

E-mail address: matovumousa@yahoo.com/m.matovu@iuiu.ac.ug 